\title{
An Effective Degumming Enzyme from Bacillus sp. Y1 and Synergistic Action of Hydrogen Peroxide and Protease on Enzymatic Degumming of Ramie Fibers
}

\author{
Fenfen Guo, Mouyong Zou, Xuezhi Li, Jian Zhao, and Yinbo Qu \\ State Key Laboratory of Microbial Technology, Shandong University, Jinan, Shandong 250100, China \\ Correspondence should be addressed to Xuezhi Li; lixz@sdu.edu.cn and Jian Zhao; zhaojian@sdu.edu.cn
}

Received 15 November 2012; Accepted 12 February 2013

Academic Editor: Suraini Abd-Aziz

Copyright (c) 2013 Fenfen Guo et al. This is an open access article distributed under the Creative Commons Attribution License, which permits unrestricted use, distribution, and reproduction in any medium, provided the original work is properly cited.

Enzymatic degumming, as an alternative to chemical processing, has attracted wide attention. However, to date, little information about other enzyme components with effective degumming except pectinase has been reported, and there is no report about the effect of bleaching agent $\left(\mathrm{H}_{2} \mathrm{O}_{2}\right)$ on enzymatic degumming and combining enzymatic degumming and $\mathrm{H}_{2} \mathrm{O}_{2}$ bleaching process. In this study, we found that the crude enzyme of wild-type Bacillus sp. Y1 had a powerful and fast degumming ability. Its PGL activity was the highest at $\mathrm{pH} 9.6-10.0$ and $60^{\circ} \mathrm{C}$ and stable at $\mathrm{pH} 7-10.5$ and $30-50^{\circ} \mathrm{C}$, having a wide scope of $\mathrm{pH}$ and temperature. Its PGL also had a high $\mathrm{H}_{2} \mathrm{O}_{2}$ tolerance, and the gum loss and brightness of fibers could be significantly improved when $\mathrm{H}_{2} \mathrm{O}_{2}$ was added into it for degumming. The synergistic action was also found between it and $\mathrm{H}_{2} \mathrm{O}_{2}$ on the degumming and bleaching of ramie fibers. All showed that it was very suitable for a joint process of enzymatic degumming and $\mathrm{H}_{2} \mathrm{O}_{2}$ bleaching. It also contained more proteins compared with a control pectinase, and its high protease content was further substantiated as a factor for effective degumming. Protease and pectinase also had a synergistic action on degumming.

\section{Introduction}

Ramie (Boehmeria nivea) is widely used in textile industry due to its excellent properties. Its fibers are considered as the longest, strongest, and silkiest in plant fibers and have excellent properties as natural textile material, such as preeminent absorption, quick drying, easy dyeing, shrinkage resistance, good bacteria, mildew, and insect resistance [1]. Moreover, it is also used in ropes, industrial packaging, twines, cordages, canvases, car outfits, and fiber-reinforced composites, among others [2].

However, decorticated ramie fibers contain 20-35\% gum, which mainly consists of pectin and hemicellulose. This gum should be removed as much as possible for most applications. Conventional degumming using $\mathrm{NaOH}$ solution consumes large amounts of chemicals and energy and causes serious environmental pollution. Therefore, developing new methods for degumming ramie fibers using microorganisms or their enzymes has attracted wide attention, and several reports are available [3-5]. Enzymatic degumming is a gentle reaction, with less damage to fibers and flexible operation, as well as easy processing and quality control, and so on. Hence, it is considered a potential alternative to chemical degumming.

In the enzymatic degumming of ramie fibers, some of the enzymes used in this process, such as pectinase, hemicellulases, and their degumming abilities, have been studied [4]. Pectinase is commonly considered as the key enzyme, and among pectinases, pectate lyase (PGL, E.C 4.2.2.2) is reported to exert more influence on the removal of pectin substances from the fibers than others do $[3,6]$, whereas high PGL activity in degumming enzymes does not necessarily mean the removal of more pectin and is insufficient for effective degumming because of the complex components of pectin $[3,5]$. A suitable enzyme system is necessary for removing pectin in ramie. Parts of literature also showed that xylanase contributes little to the degumming, and lignindegrading enzymes have little effect on the degumming 
process attributed to its little lignin content $[3,4,7]$. However, there was no report about the effect of protease with pectinase on enzymatic degumming.

In the textile technology, the bleaching of textile cellulose fabrics by $\mathrm{H}_{2} \mathrm{O}_{2}$ is an established industrial process to improve their performance in further finishing stages. $\mathrm{H}_{2} \mathrm{O}_{2}$ can decolorize, whiten fibers, and remove stains present in it. Much work has been done to elucidate the mechanism of bleaching of cellulose products [8,9]. Generally, both free radicals and perhydroxyl anions have been suggested as the intermediates in the reactions occurring between cellulosic products and $\mathrm{H}_{2} \mathrm{O}_{2}$. However, the effect of $\mathrm{H}_{2} \mathrm{O}_{2}$ on enzymatic degumming and application of combining enzymatic degumming and $\mathrm{H}_{2} \mathrm{O}_{2}$ bleaching on ramie fibers had not been reported.

In this study, we found that a cellulase-free enzyme from the wild-type Bacillus sp. Y1 had a powerful and fast degumming potential on ramie. The mechanism that underlies the effective degumming by it was studied, and its high protease content had been substantiated as a factor for effective degumming. To our knowledge, this is the first report involving the effect of $\mathrm{H}_{2} \mathrm{O}_{2}$ and protease on enzymatic degumming of ramie fibers. The present paper provides a new insight into the enzymatic degumming process and the enzyme component for effective degumming.

\section{Materials and Methods}

2.1. Bacterial Strains. All of the strains used in this study were previously isolated from a soil sample collected from bast fiber degumming factory, China, and conserved on nutrient agar slants at $4^{\circ} \mathrm{C}$ in our laboratory. Crude enzymes from the strains were produced through liquor fermentation to assess their enzymatic degumming potentials. The seed culture medium consists of $10 \mathrm{~g} / \mathrm{L}$ glucose, $5 \mathrm{~g} / \mathrm{L}$ peptone, $5 \mathrm{~g} / \mathrm{L} \mathrm{NaCl}$, $10 \mathrm{~g} / \mathrm{L} \mathrm{K}_{2} \mathrm{HPO}_{4}, 0.5 \mathrm{~g} / \mathrm{L} \mathrm{MgSO}{ }_{4} \cdot 7 \mathrm{H}_{2} \mathrm{O}$, and $5 \mathrm{~g} / \mathrm{L}$ pectin. The $\mathrm{pH}$ of the seed medium was adjusted to 8.0. The strains were incubated on a shaker at $100 \mathrm{rpm}$ and $37^{\circ} \mathrm{C}$ for $8 \mathrm{~h}$ and transferred to the liquor fermentation medium to produce enzyme. The liquid fermentation was conducted in $300 \mathrm{~mL}$ Erlenmeyer flasks by taking $50 \mathrm{~mL}$ of medium (containing the following: $54 \mathrm{~g} / \mathrm{L}$ wheat bran; $3 \mathrm{~g} / \mathrm{L}\left(\mathrm{NH}_{4}\right)_{2} \mathrm{SO}_{4} ; 2 \mathrm{~g} / \mathrm{L}$ $\mathrm{MgSO}_{4} \cdot 7 \mathrm{H}_{2} \mathrm{O} ; 1 \mathrm{~g} / \mathrm{L} \mathrm{Na}_{2} \mathrm{CO}_{3}$; and $1 \mathrm{~g} / \mathrm{L}$ Tween-80) on a swing shaker $(100 \mathrm{rpm})$ at $34^{\circ} \mathrm{C}$ for $72 \mathrm{~h}$. The $\mathrm{pH}$ of the production medium was adjusted to 8.5 prior to incubation. After fermentation, the cell-free culture supernatant was obtained and used as the crude enzyme for degumming of ramie fibers.

2.2. Enzymatic Degumming. Ramie bast fibers were obtained from Yiyang, Hunan Province, China. They were cut into $10 \mathrm{~cm}$ pieces and stored in sealed bags at room temperature until use.

Enzymatic degumming of ramie fibers was conducted in $100 \mathrm{~mL}$ flasks with enzyme at $\mathrm{pH} 8.5$ (adjusted with glycine$\mathrm{NaOH}$ buffer). The enzyme concentration (based on PGL) was $40 \mathrm{U} / \mathrm{g}$ dry ramie, and ramie fiber to liquor ratio was $1: 13(\mathrm{w}: \mathrm{v})$. Each contained $2 \mathrm{~g}$ of cut ramie fibers and $0.05 \mathrm{~g}$ of milled ramie fibers for degumming with crude enzymes and purified proteins, respectively, which were immersed in a shaking water bath with a constant temperature $\left(50^{\circ} \mathrm{C}\right)$. After the treatment, the fibers were washed and dried at $105^{\circ} \mathrm{C}$. To investigate the effect of $\mathrm{H}_{2} \mathrm{O}_{2}$ on enzymatic degumming, $0-48 \mathrm{~g} / \mathrm{L}$ (based on degumming liquor) of $\mathrm{H}_{2} \mathrm{O}_{2}$ was added into the crude enzyme of strain $\mathrm{Y} 1$ for degumming. And fibers treated with $0-48 \mathrm{~g} / \mathrm{L} \mathrm{H}_{2} \mathrm{O}_{2}$ under the same conditions served as the control.

2.3. Analysis of Fiber Properties. The chemical components of ramie fibers were measured according to the China National Standard Method (GB 5889-86). The fiber brightness of ISO was measured on a YQ-Z-48A brightness color tester according to the TAPPI standards [10]. And the brightness of fibers without any treatment was $20 \%$ ISO. The gum loss of the fibers (indicated as weight loss) was calculated as follows:

$$
\text { Gum loss }(\%)=\frac{W_{0}-W_{1}}{W_{0} \times W_{2}} \times 100
$$

where $W_{0}$ and $W_{1}$ are the weights of the dry ramie fibers before and after degumming, respectively, $W_{2}$ is the gum content of the ramie fibers before degumming.

2.4. Identification of Strain Y1. 16S rDNA nucleotide sequences was amplified from chromosomal DNA by PCR using universal oligonucleotide primers and sequenced by BGI, China. The sequences were then compared to the $16 \mathrm{~S}$ rDNA nucleotide sequences in the GenBank database by BLASTN. The $16 \mathrm{~S}$ rDNA sequences of isolate Y1 were deposited in the GenBank database with accession number JX910225.

2.5. Enzymes. A pectinase was used as the control; commercial protease and mannase were supplied by the Longda Enzymes Company, Shandong, China. Xylanase was fermented from Penicillium sp. ZCF57, which was conserved in our laboratory. Their activities were shown in Table 1.

2.6. Enzyme Assays. The PGL activity was determined at $\mathrm{pH}$ 9.6 by measuring the absorbance of unsaturated bonds in the product at $235 \mathrm{~nm}$. One enzyme unit (U) was defined as the amount of enzyme that produces $1 \mu \mathrm{mol}$ of unsaturated galacturonic acid per min with a molar extinction coefficient of 4600 [11]. The polygalacturonase (PG, EC 3.2.1.15) activity assay was performed by incubating $0.5 \mathrm{~mL}$ of the suitably diluted enzyme with $1 \mathrm{~mL}$ of $0.5 \%$ pectin (Sigma Chemical Co. type P9135) in $0.05 \mathrm{M}$ glycine- $\mathrm{NaOH}$ buffer $(\mathrm{pH} 9.6)$ at $55^{\circ} \mathrm{C}$ for $30 \mathrm{~min}$. One unit (U) was defined as the amount of enzyme required to release $1 \mu \mathrm{mol}$ of galacturonic acid from polygalacturonic acid per min under the assay conditions [12].

Xylanase (EC 3.2.1.8) and mannase (EC 3.2.1.78) activity were measured at $\mathrm{pH} 8.5$ at $50^{\circ} \mathrm{C}$ for $30 \mathrm{~min}$ according to the procedures of Helianti et al. [13] and Wang et al. [14], respectively. Filter paper (FPase) activity (FPA) of cellulase was measured as described by Liu et al. [15]. The reduced sugars released were analyzed using the DNS assay [16]. One 


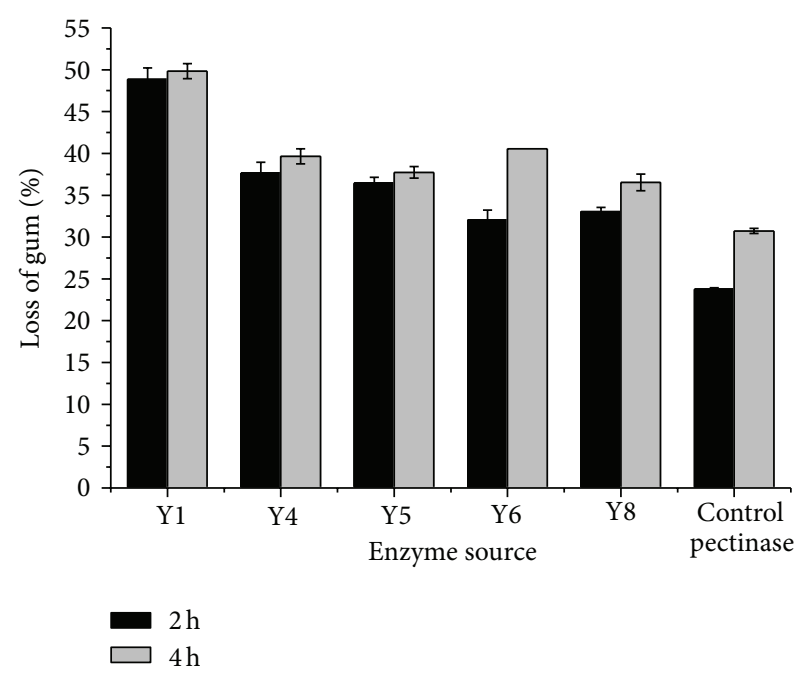

FIGURE 1: Gum loss of the ramie fibers after degumming with crude enzymes from strains and the control pectinase.

unit (U) of enzyme activity was defined as the amount of enzyme that liberated $1 \mu \mathrm{mol}$ of reducing sugar per minute under the assay conditions.

Protease activity was measured by the method of Trisina et al. [17]. One unit (U) was defined as the amount of enzyme that liberates $1 \mu \mathrm{g}$ of tyrosine per minute.

2.7. Characteristics of the Pectinase of the Crude Enzyme from Strain Y1. The optimum $\mathrm{pH}$ was determined by measuring the PGL activity in buffered reaction mixtures with $\mathrm{pH}$ ranging from 7.0 to 11.0 ( $0.05 \mathrm{M}$ glycine- $\mathrm{NaOH}$ buffer). The optimum temperature for the enzyme activity was determined by assaying enzyme activity at temperatures ranging from $30^{\circ} \mathrm{C}$ to $70^{\circ} \mathrm{C}$ at $\mathrm{pH} 9.6(0.05 \mathrm{M}$ glycine- $\mathrm{NaOH}$ buffer $)$. The $\mathrm{pH}$ and temperature stability of the enzyme were studied by exposing the enzyme to buffers with different $\mathrm{pH}$ values and incubating the enzyme at various temperatures from $30^{\circ} \mathrm{C}$ to $70^{\circ} \mathrm{C}$. The enzyme samples were taken out at different time intervals, and the residual activity was measured. $\mathrm{H}_{2} \mathrm{O}_{2}$ tolerance of the PGL was investigated by incubating the enzyme in $\mathrm{H}_{2} \mathrm{O}_{2}$ solution with concentrations ranging from $12 \mathrm{~g} / \mathrm{L}$ to $48 \mathrm{~g} / \mathrm{L}$ and assaying its residual activity at different incubation intervals. All experiments were carried out in triplicate, and mean values were applied.

2.8. Protein Analysis. Sodium dodecyl sulfate polyacrylamide gel electrophoresis (SDS-PAGE) was performed to observe protein composition and determine their molecular masses. The protein bands were directly viewed by staining with Coomassie brilliant blue R250. Molecular weight markers $(14.4 \mathrm{kDa}$ to $116 \mathrm{kDa})$ were used to estimate molecular mass.

2.9. Mass Spectrometric Analysis. Matrix-assisted laser desorption/ionization time-of-flight mass spectrometry (MALDI-TOF-MS) was employed to analyze the internal amino acid sequence of the protein bands through ingel digestion and was sequenced by the Tianjin Biochip Corporation, China.

2.10. Purification of Proteins. Concentrated culture filtrate of strain Y1 and control pectinase were loaded onto a Q Fast Flow column $(1.6 \mathrm{~cm} \times 20 \mathrm{~cm})(\mathrm{GE}$, Sweden), equilibrated with $20 \mathrm{mM}$ glycine- $\mathrm{NaOH}$ buffer (pH 9.26) and $\mathrm{NaH}_{2} \mathrm{PO}_{4}-$ $\mathrm{Na}_{2} \mathrm{HPO}_{4}$ buffer ( $\mathrm{pH}$ 7.5), respectively. The column was eluted with a linear $\mathrm{NaCl}$ gradient from $0 \mathrm{M}$ to $1 \mathrm{M}$ in the equilibration buffer at $2 \mathrm{~mL} / \mathrm{min}$ flow rate, and fractions of $1 \mathrm{~mL}$ each were collected. The protease and PGL activity of the fractions were assayed, respectively.

\subsection{Analysis of Ramie Fibers Treated with Purified Proteins} via Scanning Electron Microscopy (SEM). The ramie fibers were degummed with the purified PGL and the mixture of purified PGL and purified protease, in which the ratio of PGL to protease was consistent with that in the crude enzyme of strain Y1. The ramie fibers with different treatment were scanned via SEM to compare the changes in surface. The ramie fibers were coated with platinum and then studied. Images were taken using a JEOL JSM-6700 SEM (JEOL, Japan).

\section{Results}

3.1. Evaluation of the Degumming Potential of the Crude Enzymes from Strains. Numerous strains with degumming capabilities were isolated in our laboratory over the past 10 years. Preliminary studies showed that the crude enzymes of strain Y1, Y4, Y5, Y6, and Y8 had good potential in degumming ramie fibers. In this study, the degumming abilities of crude enzymes from strains were further evaluated and compared with a control pectinase solution under the same conditions. The gum loss of ramie fibers after $2 \mathrm{~h}$ and $4 \mathrm{~h}$ for crude enzymes from strain Y1, Y4, Y5, Y6, and Y8 and the control pectinase were shown in Figure 1. It was apparent that the crude enzyme of strain Y1 had a significantly rapid and powerful degumming potential for ramie fibers. The gum loss of the fibers degumming with the crude enzyme of strain Y1 was 2.1-fold of that with the control pectinase for $2 \mathrm{~h}$. The cellulose content of fibers changed from $71.2 \%$ for untreated to $81.0 \%$ and $81.2 \%$ for degumming after $2 \mathrm{~h}$ and $4 \mathrm{~h}$ with it, respectively. It further confirmed that the crude enzyme of strain Y1 did not damage ramie fibers. Its activities were detected (Table 1), and it was found that it consisted mainly of pectinase and protease.

3.2. Identification of Strain Y1. It was found that the strain Y1 had similar phenotypes characters to Bacillus sp., and the $16 \mathrm{~S}$ rDNA sequence of strain Y1 showed high similarities (>99\%) (data not shown) to Bacillus sp. further in the similarity search. So, the strain Y1 was identified as Bacillus sp.

3.3. Characteristics of the Pectinase of the Crude Enzyme from Bacillus sp. Y1. The characteristics of the pectinase of the crude enzyme from Bacillus sp. Y1 were also studied to assess 
TABLE 1: Activities of enzymes.

\begin{tabular}{|c|c|c|c|c|c|c|}
\hline \multirow{2}{*}{ Enzyme } & \multicolumn{6}{|c|}{ Enzyme activities (U/mL) } \\
\hline & PGL & PG & Xylanase & Mannase & FPase & Protease \\
\hline Crude enzyme of strain Y1 & 26.99 & 39.97 & 1.22 & 0.76 & 0.00 & 38.60 \\
\hline Control pectinase & 288.70 & 337.19 & 0.43 & 0.32 & 0.00 & 0.00 \\
\hline Protease & 0.00 & 0.00 & 0.00 & 0.00 & 0.00 & 2037.40 \\
\hline Xylanase & 0.00 & 0.00 & 22.58 & 0.00 & 0.00 & 0.00 \\
\hline Mannase & 0.00 & 0.00 & 0.00 & 89.79 & 0.00 & 0.00 \\
\hline
\end{tabular}

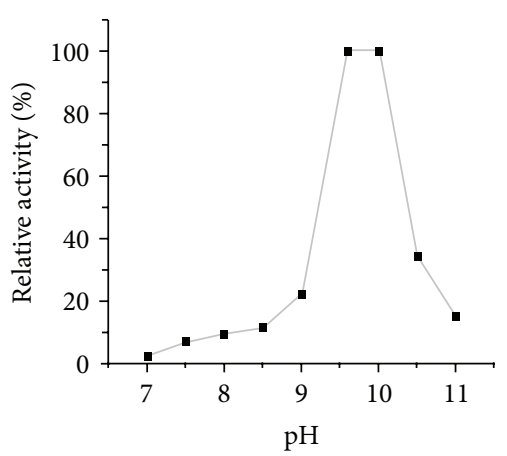

(a)

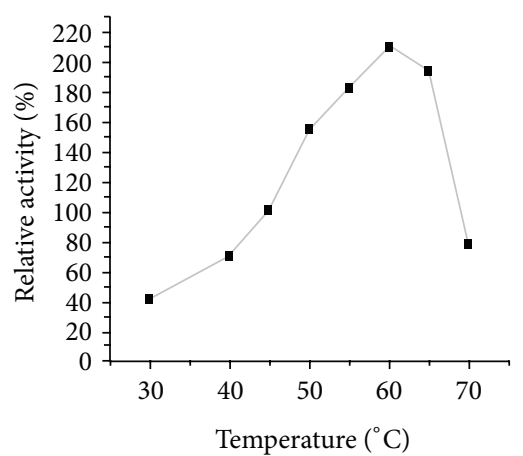

(b)

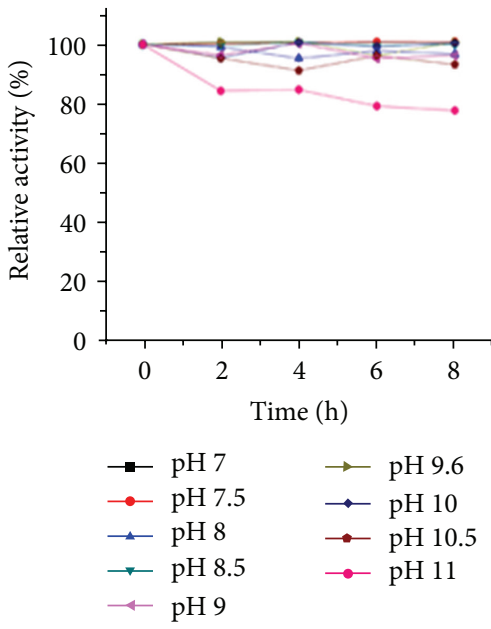

(c)

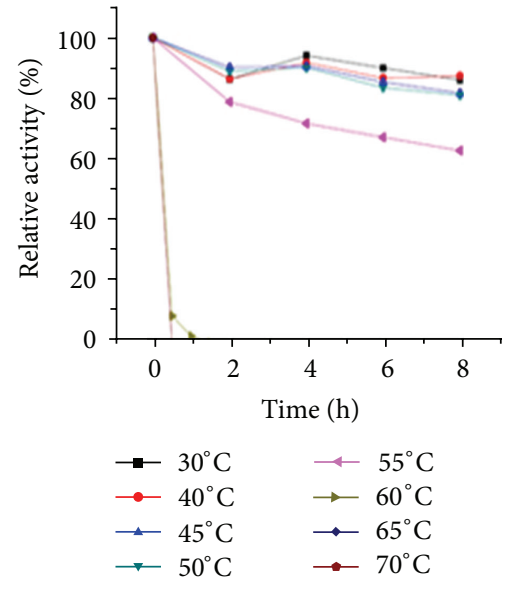

(d)

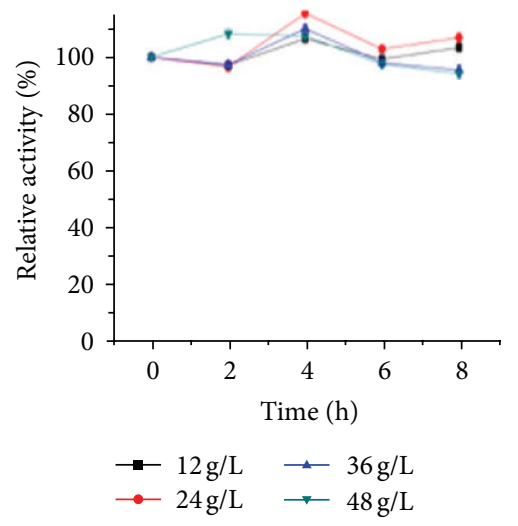

(e)

Figure 2: Properties of PGL of the crude enzyme from Bacillus sp. Y1: (a) optimum pH; (b) optimum temperature; (c) pH stability; (d) thermal stability; (e) $\mathrm{H}_{2} \mathrm{O}_{2}$ tolerance.

its potential in industrial applications. The PGL exhibited a maximum activity at $\mathrm{pH} 9.6-10.0$ (Figure $2(\mathrm{a})$ ) and $60^{\circ} \mathrm{C}$ (Figure 2(b)) and was stable at $\mathrm{pH} 7.0-10.5$ (Figure 2(c)) and $30-50^{\circ} \mathrm{C}$ (Figure $2(\mathrm{~d})$ ); at least $91 \%$ and $81 \%$ of its maximum activity were retained within $8 \mathrm{~h}$, respectively. It had wide scope of $\mathrm{pH}$ value and temperature. The residual activity was $77 \%$ of the initial activity at $\mathrm{pH} 11.0$ and $63 \%$ at $55^{\circ} \mathrm{C}$ after $8 \mathrm{~h}$. The PGL activity was unstable at temperatures up to $60^{\circ} \mathrm{C}$, and $92 \%$ of its maximum activity was lost at $60^{\circ} \mathrm{C}$ for $0.5 \mathrm{~h}$. The PGL had a high tolerance for $\mathrm{H}_{2} \mathrm{O}_{2}$, and its activity was even slightly improved in $12-48 \mathrm{~g} / \mathrm{L} \mathrm{H}_{2} \mathrm{O}_{2}$ solution (Figure 2(e)). Its characteristics indicated that the pectinase of the crude enzyme from Bacillus sp. Y1 had a good potential in ramie fiber degumming.

3.4. Effect of $\mathrm{H}_{2} \mathrm{O}_{2}$ on Enzymatic Degumming with the Crude Enzyme of Bacillus sp. Y1. The gum loss and brightness of ramie fibers could be significantly improved when a different concentration of $\mathrm{H}_{2} \mathrm{O}_{2}$ was added into the crude enzyme of Bacillus sp. Y1 for degumming, especially $24 \mathrm{~g} / \mathrm{L} \mathrm{H}_{2} \mathrm{O}_{2}$ solution, in which the gum loss and brightness increased by $21 \%$ and 1.05 -fold, respectively (Figure 3 ). It was found that the gum loss of the control samples was slightly positively 


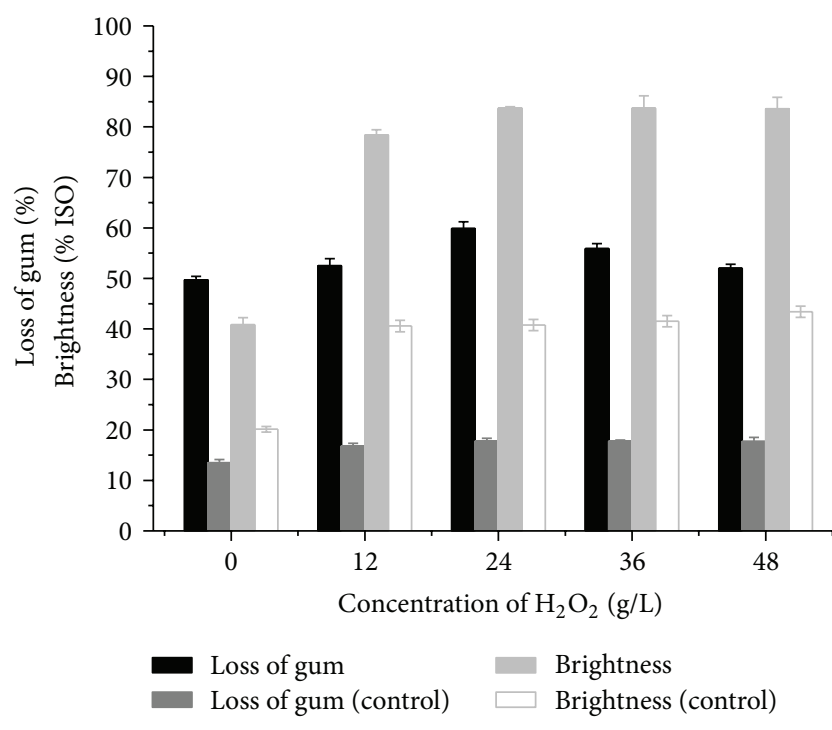

Figure 3: The gum loss and brightness of ramie fibers after degumming with the crude enzyme of Bacillus sp. Y1 and different concentration of $\mathrm{H}_{2} \mathrm{O}_{2}$ for $4 \mathrm{~h}$. Control: fibers treated with $0-48 \mathrm{~g} / \mathrm{L}$ $\mathrm{H}_{2} \mathrm{O}_{2}$ under the same conditions.

affected by $\mathrm{H}_{2} \mathrm{O}_{2}$ alone. It was also apparently observed that higher gum loss and brightness were achieved by mixture of the crude enzyme of Bacillus sp. $\mathrm{Y} 1$ and $\mathrm{H}_{2} \mathrm{O}_{2}$ than the amount obtained by using single, which means that there was a synergistic action between the crude enzyme of Bacillus sp. $\mathrm{Y} 1$ and $\mathrm{H}_{2} \mathrm{O}_{2}$ on the degumming and bleaching of ramie fibers. The crude enzyme from Bacillus sp. Y1 was very valuable for combining enzymatic degumming or bioscouring [9] and $\mathrm{H}_{2} \mathrm{O}_{2}$ bleaching of ramie fibers in the industry.

3.5. Enzyme Composition Analysis. To interpret why the gum loss of fibers for the crude enzyme of Bacillus sp. Y1 was much more than the control pectinase at the same conditions (Figure 1), the enzyme compositions of the crude enzyme from Bacillus sp. Y1 and the control pectinase were visually compared using SDS-PAGE and analyzed via MALDI-TOF (MS/MS). The main different protein bands in enzyme composition between them were shown in Figure 4, and it was found that more protein types were contained in the crude enzyme of Bacillus sp. Y1. For instance, obviously, a much greater amount of protease was present in the crude enzyme of Bacillus sp. Y1 compared with the control enzyme (Figure 4). Besides, the high level of the protease activity in the crude enzyme of Bacillus sp. Y1 and no protease activity in control pectinase (Table 1) also confirmed this performance.

\subsection{Identification of the Effect of Protease on Enzymatic} Degumming. To identify whether protease creates the significant difference in gum loss between the crude enzyme of Bacillus sp. Y1 and the control pectinase, commercial protease, xylanase, and mannase were added to the control pectinase for degumming with equal amount of each enzyme activity with the crude enzyme of Bacillus sp. Y1 in degumming (Figure 5). These three enzymes had no other enzyme activities (Table 1). Fibers treated with glycine- $\mathrm{NaOH}$ buffer, mannase, xylanase, protease, and mixture of mannase, xylanase, and protease under the same conditions served as the control, respectively. The results showed that xylanase and mannase had a barely positive effect on degumming of ramie, and protease had a remarkable effect, making the gum loss increased by $26 \%$ compared with the control enzyme alone (Figure 5). This increase directly indicated that protease was an important component in the enzymatic degumming of ramie. Figure 5 also showed that protease and pectinase had a synergistic action on the degumming of ramie fibers, due to higher gum loss that could be obtained by mixture of the control pectinase and protease than the amount achieved by using a single enzyme. By measuring activities of PGL in the liquor solution during degumming, it was found that the stability of PGL was not negatively affected when the protease was added into the control pectinase (data not shown).

To further verify the effect of protease on ramie degumming, the protease and PGL were purified and then degumming with them. After concentrated culture filtrate of Bacillus sp. Y1 was loaded onto Q Fast Flow column, a single band with a molecular weight of $28 \mathrm{kDa}$ could be detected via SDS-PAGE in elution peak (Figure 6(a)). It was the purified protease identified via enzyme determination and MS/MS (Figure 4). A single band with a molecular weight of $45 \mathrm{kDa}$ also could be detected via SDS-PAGE in penetration peak when concentrated control pectinase was loaded onto Q Fast Flow column (Figure 6(b)). It was the purified PGL that was confirmed through enzyme determination and MS/MS (Figure 4). When degumming with a mixture of purified PGL and purified protease, in which the ratio of PGL to protease was consistent with that in the crude enzyme of strain Y1, the gum loss of ramie fibers increased by $74 \%$ compared with the purified PGL alone for $4 \mathrm{~h}$, and the synergistic action of protease on the degumming of ramie fibers was also observed (data not shown). The surface change of ramie fibers degumming with the purified proteins was shown in Figure 7 by SEM observation.

\section{Discussion}

A number of the genus Bacillus and related genera are known to produce extracellular enzymes, which have been applied in ramie fibers industry $[3,5]$. Even though some studies about enzymatic degumming had already been done, more effective degumming enzymes are still needed to boost the application of enzymatic degumming technology in the industry [3-5]. In the present study, the wild-type Bacillus sp. Y1, which had a cellulase-free enzyme for fast and forceful degumming, was screened. Culture supernatants from Amycolata sp. have been reported to be most effective in fiber separation and reducing the gum content of ramie fiber by $30 \%$ in $15 \mathrm{~h}$ with $240 \mathrm{U}$ PGL/g ramie fibers [4]. However, with the crude enzyme of Bacillus sp. Y1 resulted in gum loss up to $48.7 \%$ after degumming with shorter time $(2 \mathrm{~h})$ and lower PGL dosage (40 U PGL/g ramie fibers). Furthermore, the fiber brightness (40.8\% ISO) (Figure 3) was higher than that 


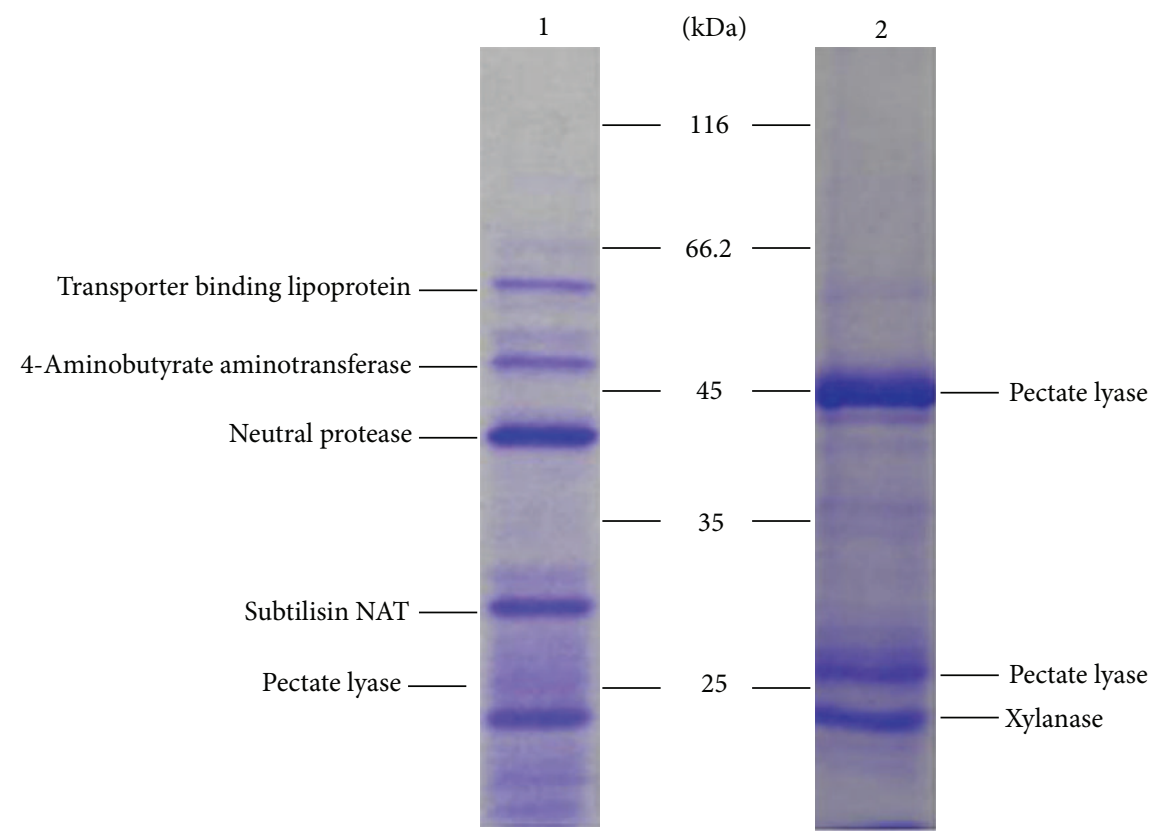

FIGURE 4: Differences between the enzyme composition of the crude enzyme of Bacillus sp. Y1 (1) and control pectinase (2) through SDSPAGE and MALDI-TOF (MS/MS).

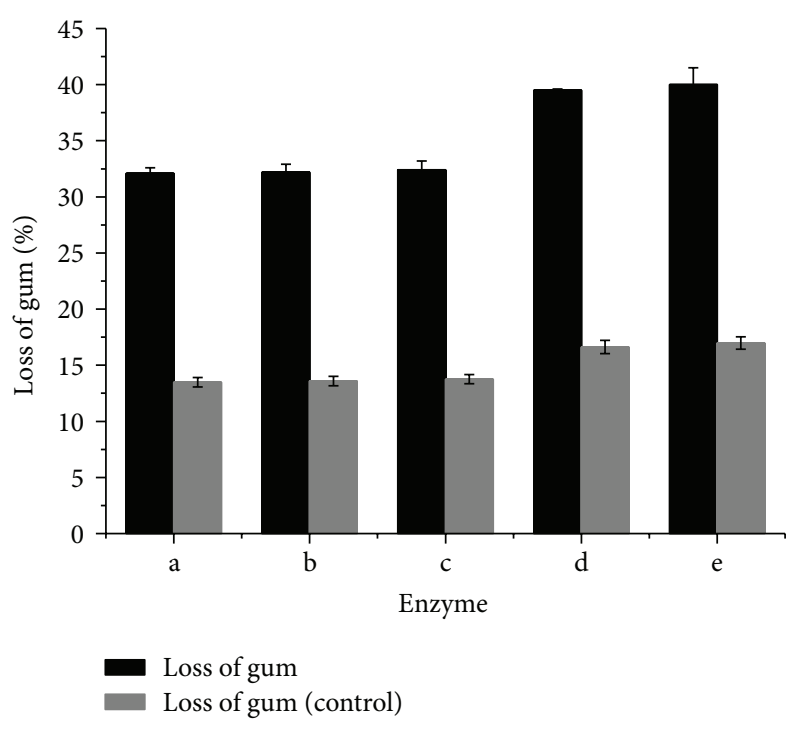

FIGURE 5: The effect of protease, xylanase, and mannase on the ramie degumming for $4 \mathrm{~h}$ : (a) control pectinase; (b) control pectinase + mannase; (c) control pectinase + xylanase; (d) control pectinase + protease; (e) control pectinase + mannase + xylanase + protease. Control: fibers treated with glycine- $\mathrm{NaOH}$ buffer, mannase, xylanase, protease and mixture of mannase, xylanase, and protease under the same conditions for (a), (b), (c), (d), and (e), respectively.

obtained by degumming with a mixed supernatant of Bacillus sp. NT-39 and NT-53 (37.8\% ISO) [3].

The PGL activity of Bacillus sp. Y1 was highest at $\mathrm{pH} 9.6-$ 10.0 and $60^{\circ} \mathrm{C}$. These are comparable with those of Bacillus sp. KSM-P15, having optimal activity around $\mathrm{pH} 10.5$ and $50-55^{\circ} \mathrm{C}[18]$, and superior to several alkaline pectinases reported by Nasuno and Starr [19], Davé and Vaughn [20], and Magro et al. [21], exhibiting the maximum activity at $\mathrm{pH} 8.5$ and $45^{\circ} \mathrm{C}$, and $\mathrm{pH} 8.0-8.5$ and $60^{\circ} \mathrm{C}, \mathrm{pH} 8.0$ and $30-40^{\circ} \mathrm{C}$, respectively. The PGL was stable at $\mathrm{pH} 7.0-10.5$ and $30-50^{\circ} \mathrm{C}$, and at least $81 \%$ of its maximum activity was retained within $8 \mathrm{~h}$. These also showed that it was suitable for degumming ramie. For example, the wide scope of $\mathrm{pH}$ value and temperature made the enzyme of easier use in industrial process because the degumming could be conducted at ambient temperature, and the $\mathrm{pH}$ did not need to be adjusted during the degumming process.

The pectinase of the crude enzyme from Bacillus sp. Y1 also had a high tolerance for $\mathrm{H}_{2} \mathrm{O}_{2}$, and its activity was even slightly improved in $12-48 \mathrm{~g} / \mathrm{L} \mathrm{H}_{2} \mathrm{O}_{2}$ solution, which maybe attributed to the action of free radicals and perhydroxyl anions from $\mathrm{H}_{2} \mathrm{O}_{2}$ [9]. What is more, a higher gum loss and fiber brightness were achieved when $\mathrm{H}_{2} \mathrm{O}_{2}$ was added into the crude enzyme of Bacillus sp. Y1 for degumming. The highest fiber brightness ( $83.7 \%$ ISO) was much higher than that when using the crude enzyme of Bacillus sp. Y1 (40.8\% ISO) and $\mathrm{H}_{2} \mathrm{O}_{2}$ alone (40.8\% ISO) [3]. Based on the results, it was suggested that the crude enzyme of Bacillus sp. $\mathrm{Y} 1$ and $\mathrm{H}_{2} \mathrm{O}_{2}$ had a synergistic action on the degumming and bleaching of ramie fibers (Figure 3). Zheng et al. reported that enzymatic degumming could result in the removal of part chromophoric material linking gum components [3]. Ibrahim et al. also reported that the pectinase has the ability to hydrolyze and transform the water-insoluble polygalacturonic acid into water-soluble oligomers, thereby enhancing the release of other hydrophobic noncellulosic impurities away from the wall, as well as facilitating and increasing the extent of $\mathrm{H}_{2} \mathrm{O}_{2}$ bleaching via creation of more available active-surface area 


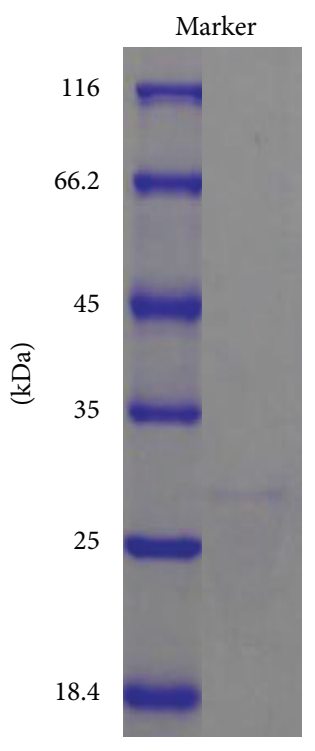

(a)

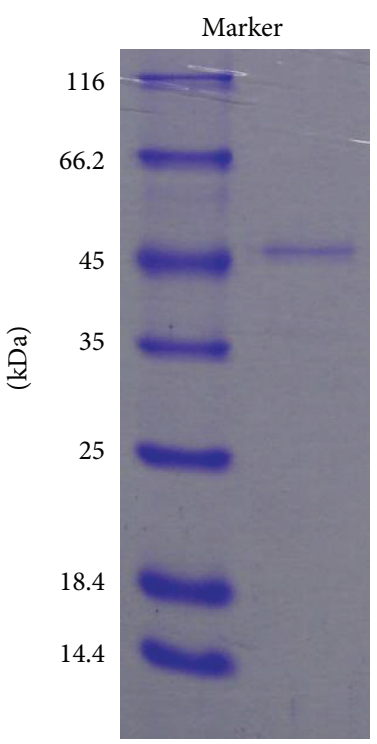

(b)

FIGURE 6: The purified protease (a) and purified PGL (b) separated from the crude enzyme of Bacillus sp. Y1 and control pectinase, respectively.

for further modification, and $\mathrm{H}_{2} \mathrm{O}_{2}$ further removes the colored substances and stains present in the fibers increasing the contact area of pectinase and pectic substance to promote the enzyme action [9]. So, this crude enzyme could be used in combining enzymatic degumming or bioscouring and $\mathrm{H}_{2} \mathrm{O}_{2}$ bleaching. Therefore, this enzyme and this process could not only decrease the process, device, and energy consumption to reduce the production costs but also obtain higher gum loss and fiber brightness. On the basis of these results, the crude enzyme of Bacillus sp. Y1 showed great potential in the fiber processing industry.

Few studies have focused on other effective enzyme compositions for fiber degumming except pectinase. Generally, the PGL is known as the key enzyme $[3,6]$. However, hemicellulases, for example, xylanase and mannase, do not significantly contribute to ramie degumming $[3,6]$, with which our results were consistent (Figure 5). In this study, we found that the crude enzyme system of Bacillus sp. Y1 had a greatly higher content of protease than that of the control pectinase (Figure 4 and Table 1), and the protease was substantiated to play a much more significant role in degumming ramie (Figure 5). Protease is one of the most important industrial enzymes in sericin (gum) removal from silk yarn [22]. However, few reports on the application of protease in ramie degumming have been published.

Using Kjeldahl determination [23], it was found that the ramie used in the current paper contained 3.3\% protein, of which $67 \%$ were removed after degumming with the crude enzyme of Bacillus sp. Y1 and commercial protease, and only $24 \%$ were removed by glycine- $\mathrm{NaOH}$ buffer after degumming with the control pectinase, because it was equal to the control experiment with only glycine- $\mathrm{NaOH}$ buffer. This corresponded to the protease activity in the crude enzyme of Bacillus sp. Y1 (38.6 U/mL) and control pectinase $(0 \mathrm{U} / \mathrm{mL})$ (Table 1). But the increased gum loss was much higher than the effect of protein removal on weight loss. This significant difference of gum loss between the crude enzyme of Bacillus sp. Y1 and control pectinase (Figure 1) should attribute to not only the protein removal but also the promotion effect of protease on pectinase in degumming with the crude enzyme of Bacillus sp. Y1.

This suppose has been substantiated by measuring the concentration of released galacturonic acid in degumming liquid using the absorbance of unsaturated bonds at $235 \mathrm{~nm}$ [11] and reducing groups at $276 \mathrm{~nm}$ [24]. Kapoor et al. also used the determination of the concentration of released galacturonic acid to indicate the degumming efficiency [5]. A previous study also found that there was a good correlation between the gum loss and the released galacturonic acid measured at $235 \mathrm{~nm}$ and $276 \mathrm{~nm}$ (data not shown). Samples with no ramie fibers as the substrate were used as control. The results showed that the concentration of removed polygalacturonic acid in degumming liquid of degumming with mixture of control pectinase and commercial protease increased by $26 \%$ and $24 \%$, respectively, meaning that the removed of polygalacturonic acid from ramie increased more than $24 \%$, compared to with the control pectinase alone. Kirby et al. have reported that pectin extracts contain a mixture of pectin polysaccharides and protein-pectin complexes, and these protein-pectin complexes consist of pectin molecules with protein attached to one end of the pectin chain [25]. So, the protease should remove the protein in the pectin-protein complexes, which helps induce a reaction between pectin and pectinase, and leads to more pectin degradation and removal.

To further substantiate the effect of protease on ramie degumming, the protease and PGL were purified (Figure 6), and the comparative degumming experiments with them were carried out. The concentration of released galacturonic acid in degumming liquor that measured at $235 \mathrm{~nm}$ and $276 \mathrm{~nm}$ increased by $44 \%$ and $64 \%$, respectively, if using a 


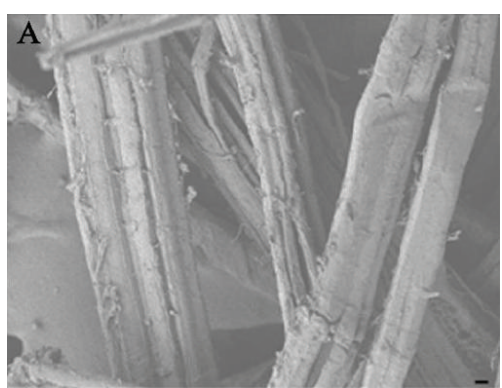

(a)

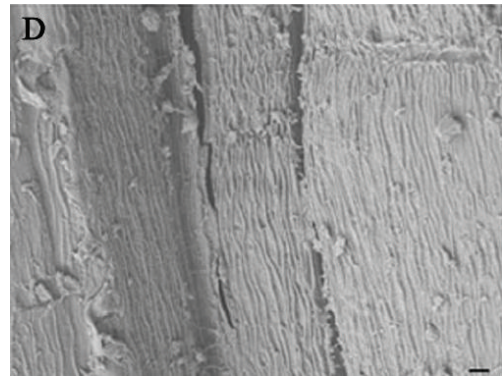

(d)

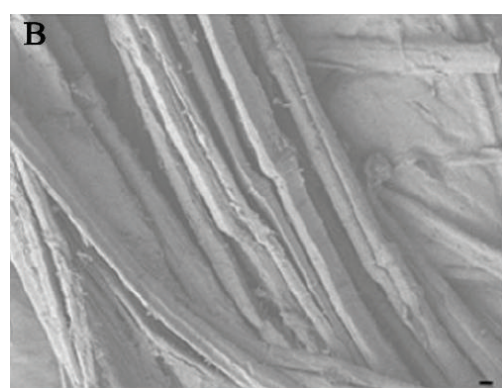

(b)

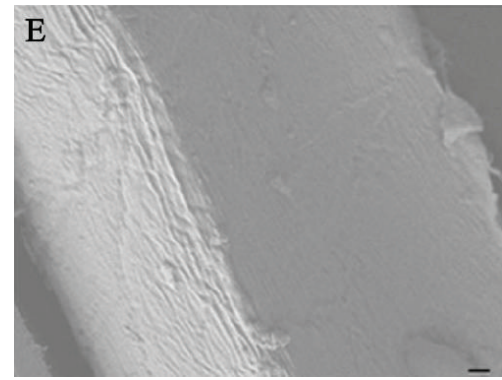

(e)

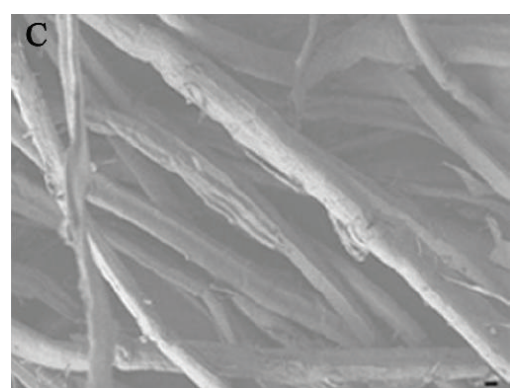

(c)

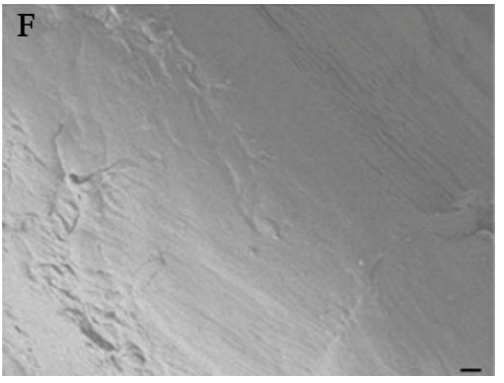

(f)

FIGURE 7: SEM observation of ramie fibers before (a,d) and after treated with the purified PGL (b,e) and the mixture of purified PGL and purified protease (c, f). Scale bars: $10 \mu \mathrm{m}$ (a, b, and c) and $1 \mu \mathrm{m}(\mathrm{d}, \mathrm{e}$, and f).

mixture of purified PGL and purified protease instead of the purified PGL alone. These significant increments in removed polygalacturonic acid further substantiated the significant effect of protease on ramie degumming.

SEM observation was also used for studying the change of fibers before and after degumming with the purified protein, and shown in Figure 7. After degumming with purified PGL (Figures $7(\mathrm{~b})$ and $7(\mathrm{e})$ ) or mixture of purified PGL and purified protease (Figures $7(\mathrm{c})$ and $7(\mathrm{f})$ ), the fibers were separated and the surface of fibers was much smoother with the removal of the encrusting materials and almost no cell wall debris remaining compared with the untreated (Figures $7(\mathrm{a})$ and $7(\mathrm{~d})$ ) and chemically degummed fibers [5]. However, application of mixture of purified PGL and purified protease produced fibers with an even smoother surface (Figures 7(c) and 7(f)), a complete removal of gummy material, than treated with the purified PGL alone (Figures 7(b) and 7(e)) and chemical and subsequently pectinase [5]. Furthermore, separation of the fibers was also significantly improved with mixture of purified PGL and purified protease compared to with the purified PGL alone. These appearances provide another strongly visible evidence for the important role of protease in degumming. The results provide new insights into the genetic modification of degumming strain and improvement of degumming enzyme system.

\section{Conclusion}

The crude enzyme of Bacillus sp. Y1 was found to have a powerful and fast degumming ability on ramie by screening wild-type strains. It mainly consisted of pectinase and protease from the active component of the enzyme. And its alkaline pectinase had suitable characteristics for degumming process, especially the high tolerance for $\mathrm{H}_{2} \mathrm{O}_{2}$. What is more, the gum loss and brightness of ramie fibers could be significantly improved when different concentration of $\mathrm{H}_{2} \mathrm{O}_{2}$ was added into it for degumming. The synergistic action was also found between it and $\mathrm{H}_{2} \mathrm{O}_{2}$ on the degumming and bleaching of ramie fibers. All showed that it was very suitable for combining enzymatic degumming and $\mathrm{H}_{2} \mathrm{O}_{2}$ bleaching, which could reduce process and devices costs. It also contained more proteins compared with the control pectinase, and protease component in it was further substantiated to play an important role in the degumming process. There was also a synergistic action between protease and pectinase on degumming. We believe that these results are very valuable for boosting the study of degumming enzymes, degumming mechanism, and application of enzymatic degumming technology in the industry.

\section{Conflict of Interests}

The authors declare that they have no conflict of interests.

\section{Acknowledgments}

This study was supported by Grants from the National Basic Research Program of China (no. 2011CB707401), the National High Technology Research and Development Program of China (no. 2012AA022203B), the National Natural Sciences Foundation of China (no. 31170107), and the Natural Sciences Foundation of Shandong Province (no. ZR2010CM023). 


\section{References}

[1] B. Wang, D. Peng, L. Liu, Z. Sun, N. Zhang, and S. Gao, "An efficient adventitious shoot regeneration system for ramie (Boehmeria nivea Gaud) using thidiazuron," Botanical Studies, vol. 48, no. 2, pp. 173-180, 2007.

[2] J. Chen, J. Yi, P. Sun, Z. T. Liu, and Z. W. Liu, "Grafting from ramie fiber with poly(MMA) or poly(MA) via reversible addition-fragmentation chain transfer polymerization," Cellulose, vol. 16, no. 6, pp. 1133-1145, 2009.

[3] L. Zheng, Y. Du, and J. Zhang, "Degumming of ramie fibers by alkalophilic bacteria and their polysaccharide-degrading enzymes," Bioresource Technology, vol. 78, no. 1, pp. 89-94, 2001.

[4] F. Brühlmann, M. Leupin, K. H. Erismann, and A. Fiechter, "Enzymatic degumming of ramie bast fibers," Journal of Biotechnology, vol. 76, no. 1, pp. 43-50, 2000.

[5] M. Kapoor, Q. K. Beg, B. Bhushan, K. Singh, K. S. Dadhich, and G. S. Hoondal, "Application of an alkaline and thermostable polygalacturonase from Bacillus sp. MG-cp-2 in degumming of ramie (Boehmeria nivea) and sunn hemp (Crotalaria juncea) bast fibres," Process Biochemistry, vol. 36, no. 8-9, pp. 803-807, 2001.

[6] F. Bruhlmann, Kwi Suk Kim, W. Zimmerman, and A. Fiechter, "Pectinolytic enzymes from actinomycetes for the degumming of ramie bast fibers," Applied and Environmental Microbiology, vol. 60, no. 6, pp. 2107-2112, 1994.

[7] L. Xiao, G. X. Wang, and G. J. Chen, "The research advancement of the enzymatic degumming of ramie (Boehmeria nivea): a review," The Journal of Microbiology, vol. 31, no. 5, pp. 101-105, 2004.

[8] R. E. Brooks and S. B. Moore, "Alkaline hydrogen peroxide bleaching of cellulose," Cellulose, vol. 7, no. 3, pp. 263-286, 2000.

[9] N. A. Ibrahim, M. El-Hossamy, M. M. Hashem, R. Refai, and B. M. Eid, "Novel pre-treatment processes to promote linencontaining fabrics properties," Carbohydrate Polymers, vol. 74, no. 4, pp. 880-891, 2008.

[10] J. Zhao, X. Li, Y. Qu, and P. Gao, "Xylanase pretreatment leads to enhanced soda pulping of wheat straw," Enzyme and Microbial Technology, vol. 30, no. 6, pp. 734-740, 2002.

[11] Y. Wang, Z. Wang, G. Du et al., "Enhancement of alkaline polygalacturonate lyase production in recombinant Pichia pastoris according to the ratio of methanol to cell concentration," Bioresource Technology, vol. 100, no. 3, pp. 1343-1349, 2009.

[12] E. Nakkeeran, M. K. Gowthaman, S. Umesh-Kumar, and R. Subramanian, "Techno-economic analysis of processes for Aspergillus carbonarius polygalacturonase production," Journal of Bioscience and Bioengineering, vol. 113, no. 5, pp. 634-640, 2012.

[13] I. Helianti, N. Nurhayati, M. Ulfah, B. Wahyuntari, and S. Setyahadi, "Constitutive high level expression of an endoxylanase gene from the newly isolated Bacillus subtilis AQ1 in Escherichia coli," Journal of Biomedicine and Biotechnology, vol. 2010, Article ID 980567, 12 pages, 2010.

[14] Y. Wang, P. Shi, H. Luo et al., "Cloning, over-expression and characterization of an alkali-tolerant endo- $\beta$-1,4-mannanase from Penicillium freii F63," Journal of Bioscience and Bioengineering, vol. 113, no. 6, pp. 710-714, 2012.

[15] K. Liu, X. Lin, J. Yue et al., "High concentration ethanol production from corncob residues by fed-batch strategy," Bioresource Technology, vol. 101, no. 13, pp. 4952-4958, 2010.
[16] G. L. Miller, "Use of dinitrosalicylic acid reagent for determination of reducing sugar," Analytical Chemistry, vol. 31, no. 3, pp. 426-428, 1959.

[17] J. Trisina, F. Sunardi, M. T. Suhartono, and R. R. Tjandrawinata, "DLBS1033, a protein extract from lumbricus rubellus, possesses antithrombotic and thrombolytic activities," Journal of Biomedicine and Biotechnology, vol. 2011, Article ID 519652, 7 pages, 2011.

[18] T. Kobayashi, K. Koike, T. Yoshimatsu et al., "Purification and properties of a low-molecular-weight, high-alkaline pectate lyase from an alkaliphilic strain of Bacillus," Bioscience, Biotechnology and Biochemistry, vol. 63, no. 1, pp. 65-72, 1999.

[19] S. Nasuno and M. P. Starr, "Polygalacturonic acid transeliminase of Xanthomonas campestris," Biochemical Journal, vol. 104, no. 1, pp. 178-185, 1967.

[20] B. A. Davé and R. H. Vaughn, "Purification and properties of an polygalacturonic acid trans-eliminase produced by Bacillus pumilus," Journal of Bacteriology, vol. 108, no. 1, pp. 166-174, 1971.

[21] P. Magro, L. Varvaro, G. Chilosi, C. Avanzo, and G. M. Balestra, "Pectolytic enzymes produced by Pseudomonas syringae pv. Glycinea," FEMS Microbiology Letters, vol. 117, no. 1, pp. 1-5, 1994.

[22] P. Chim-Anage and N. Romsomsa, "Optimized conditions for silk degumming protease production from Bacillus sp. by response surface methodology: an abstract," Journal of Bioscience and Bioengineering, vol. 108, pp. S114-S134, 2009.

[23] A. D. Eckard, K. Muthukumarappan, and W. Gibbons, "Analysis of casein biopolymers adsorption to lignocellulosic biomass as a potential cellulase stabilizer," Journal of Biomedicine and Biotechnology, vol. 2012, Article ID 745181, 11 pages, 2012.

[24] A. Carrillo-López, A. Cruz-Hernández, A. Cárabez-Trejo, F. Guevara-Lara, and O. Paredes-López, "Hydrolytic activity and ultrastructural changes in fruit skins from two prickly pear (Opuntia sp.) varieties during storage," Journal of Agricultural and Food Chemistry, vol. 50, no. 6, pp. 1681-1685, 2002.

[25] A. R. Kirby, A. J. MacDougall, and V. J. Morris, "Sugar beet pectin-protein complexes," Food Biophysics, vol. 1, no. 1, pp. 51$56,2006$. 

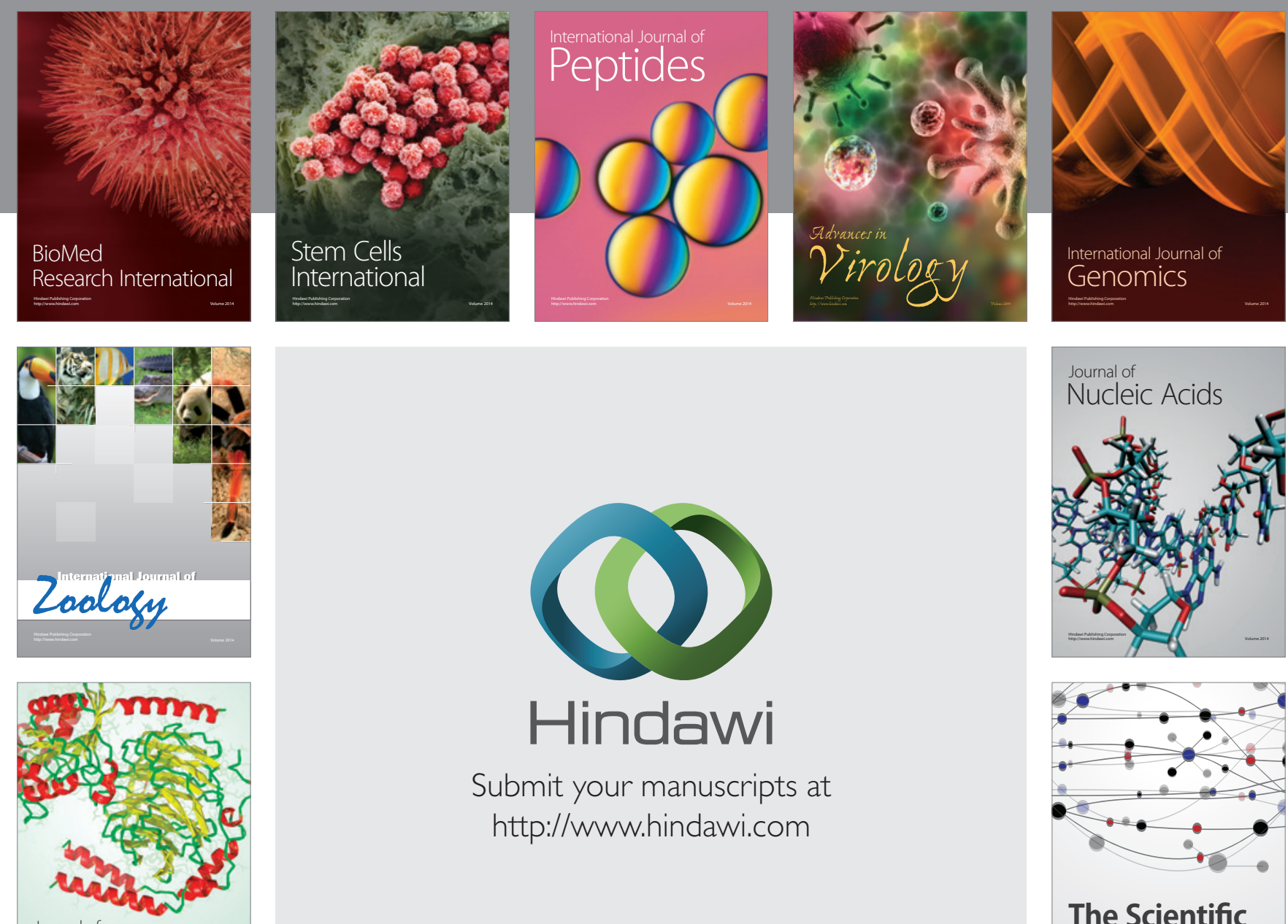

Submit your manuscripts at

http://www.hindawi.com

Journal of
Signal Transduction
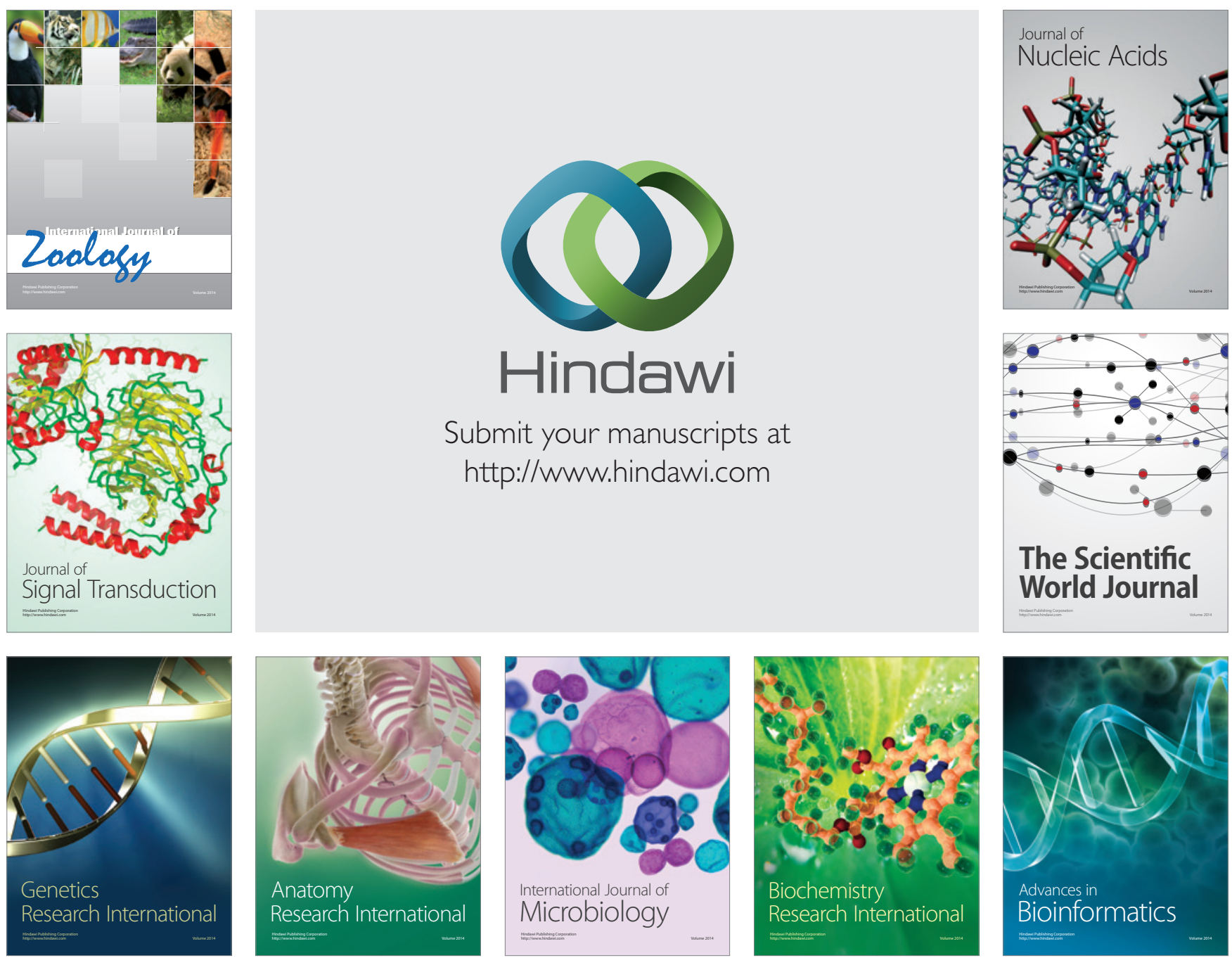

The Scientific World Journal
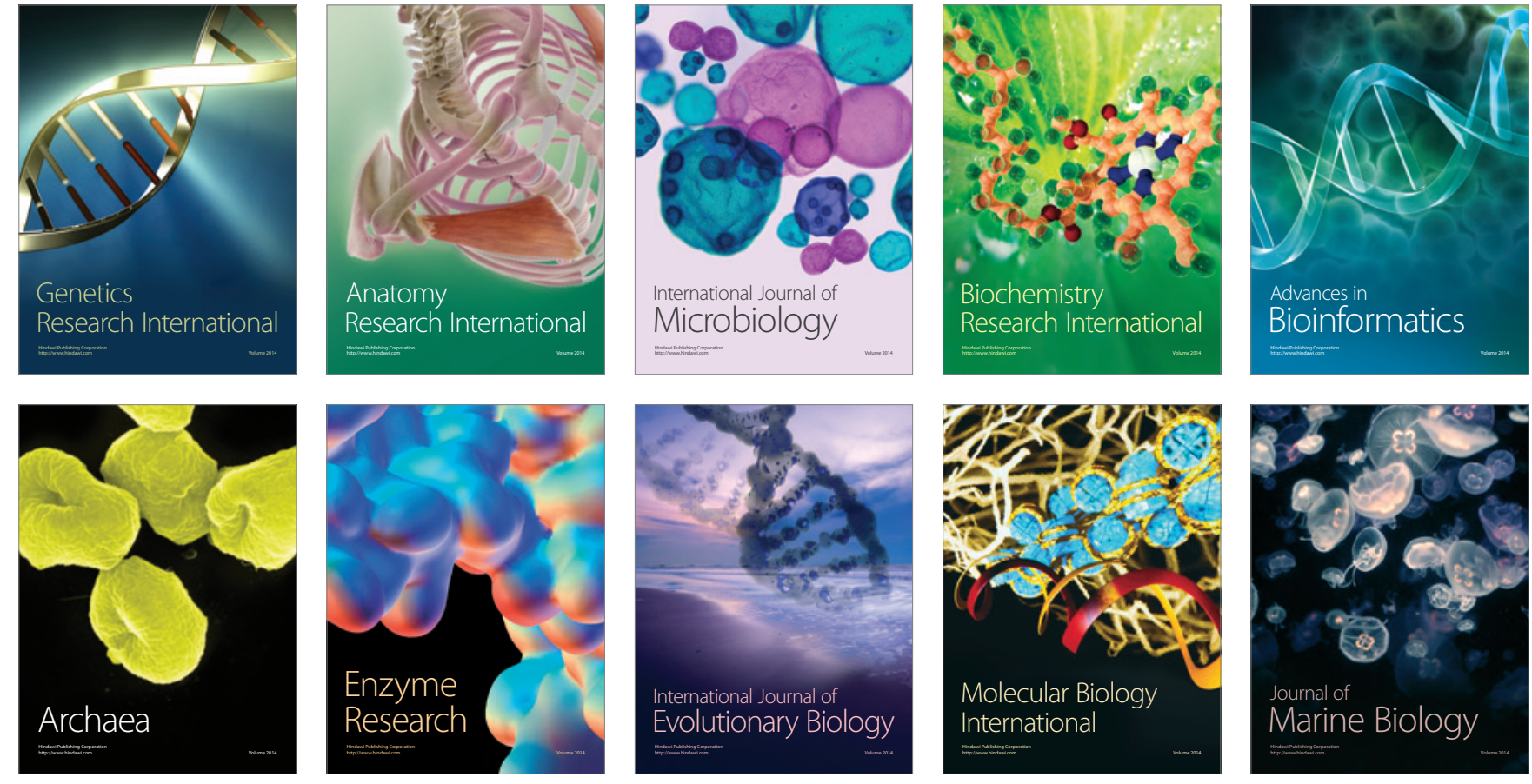